Eva Reyes G.

Profesora en la Universidad Católica de la Santísima Concepción

Chile

\title{
La reciprocidad. Algunas reflexiones a partir de las Homilías I a IV de Gregorio de Nisa
}

\section{PRELIMINARES:}

En esta reflexión quisiera plantear el tema de la reciprocidad entre el alma y Dios en las Homilías I a IV de Gregorio de Nisa. Como punto de partida abordaré algunos elementos filosóficos presentes en la obra del Niseno, que nos conducirán a la comprensión cristiana del sujeto situado ante Dios.

\section{ALGUNOS PRESUPUESTOS FILOSÓFICOS}

Como es sabido, Gregorio subraya la diferencia entre la naturaleza del ser creado y la del ser increado, entre el ser finito y el ser infinito. ¿Quiere esto decir que nos encontramos ante una filosofía de la desesperanza, ya que el infinito será siempre inalcanzable para lo finito? En términos del Niseno ¿podría plantearse la idea que el hombre inmerso en este movimiento infinito hacia el infinito nunca podrá alcanzar la ansiada posesión del Bien (1)?

\section{Aquel movimiento infinito hacia el infinito}

En referencia a este dato Spira ha escrito lo siguiente: "La epéktasis paulina es interpretada por Gregorio como progreso infinito en el sentido filosófico. Las consecuencias de esta nueva concepción del arista son considerables. Pues se fundan en un movimiento infinito hacia el infinito, Gregorio trasciende la lógica aristotélica, que rechaza todo progreso al infinito. Esta nueva filosofía del infinito ha hecho de Gregorio el inspirador de la mística europea y por lo mismo uno de los padres del dinamismo progresista que caracteriza nuestra civilización occi-

(1) Cf. Mateo-Seco, L.F., ¿Progreso o inmutabilidad en la visión beatífica? Apuntes de la historia de la teología. En: Scripta Teológica 29 (1997) 13-26. 
dental" (2). Es por ello que Las Homilías del Cantar de los Cantares han sido leídas en una multitud de ocasiones a la luz de lo que ha escrito J. Daniélou en torno a la epéktasis, es decir, la contemplación humana de Dios en sus cimas más altas como un éxtasis en constante superación de sí mismo. Este término se inspira en Fil 3,13 donde San Pablo compara su vida interior a la del corredor, siempre en tensión hacia la meta, intentando superarse a sí mismo.

En esta perspectiva Daniélou piensa que Gregorio presenta una novedad respecto del pensar griego, en cuanto para estos la perfección humana es sinónimo de quietud y acabamiento; para Gregorio consistiría en el progreso y en la tensión sin fin hacia el bien. Por otra parte, no se puede afirmar que Gregorio piense la vida en el cielo como un perpetuo status viatoris, sino que concibe la idea de un progreso indefinido de una contemplación ya alcanzada definitivamente. En fin, responder afirmativamente a la pregunta planteada: ¿Quiere esto decir que nos encontramos ante una filosofía de la desesperanza?, sería alejarnos del pensamiento del Niseno y ello nos permitirá plantear el tema de la siguiente forma:

\section{Posibilidad del alma en alcanzar lo divino}

Gregorio sitúa el carácter indefinido de la búsqueda fundado sobre la idea primordial de la inaccesibilidad de la esencia divina. Pero ello no significa que Dios sea inalcanzable, sino que aun siendo poseído siempre sobrepasa al que lo posee. Es decir, mientras más alcanza lo deseado, más lo desea (3).

Por el propio Cantar sabemos que el Esposo es Cristo y es quien besa al alma, la llama, la hace subir en constantes ascensiones, y mantiene un diálogo de amor que la diviniza. Para Gregorio esto solo es posible si Cristo es Dios verdaderamente, el autor es consciente que su teología mística debe descansar sobre una sólida cristología y soteriología. Por ello es interesante destacar la importancia que ofrece nuestro autor a la mediación de Cristo en la ascensión espiritual del alma, esto equivale a decir en la conformación, donde el alma encuentra su divinización.

En este sentido la teología mística de Gregorio, que expresa la unión del alma con el Verbo, se encuentra apoyada en la teología dogmática, en la doctrina de la unión del Verbo con la humanidad y en el concepto de Mediador. M. Canévet ha hecho notar acertadamente que Gregorio privilegia la noción de mediación de Cristo en relación al texto bíblico de 1 Tim 2,5 "único es el mediador de Dios y los hombres" (4). Así, Gregorio utiliza el término no solo para hablar de la unión entre el alma y Cristo, sino para subrayar la verdad de la encarnación describiendo con frecuencia el misterio de encarnación como iniciativa del Verbo quien ha tomado sobre sí la naturaleza humana (5).

(2) Spira, A., Le temps d'un homme selon Aristote et Grégoire de Nysse. En: Colloques internationaux du CNRS (1984) 289s.

(3) Cf. Mateo-Seco, op. cit., 13-26.

(4) Cf. Canévet Mariette, Grégoire de Nysse et L'hermeneutique Biblique. Études Agustiniennes Paris 1983. 243-246.

(5) Cf. CCEE II, 41 . 
En síntesis, para el pensamiento griego la perfección humana es sinónimo de quietud y acabamiento, para Gregorio consistiría en el progreso y en la tensión sin fin hacia el bien donde el alma tiene acceso a la divinidad, posibilitada por la única mediación de Cristo, quien es Dios verdaderamente. Una vez situada la naturaleza humana en su dimensión de horizontalidad con Dios, expresará la alegría del encuentro mediante los símbolos de la reciprocidad.

\section{LOS SÍMBOLOS DE LA RECIPROCIDAD}

La reciprocidad según $M$. Canévet (6) en las palabras del Niseno es comprendida como aquella participación del alma en la vida divina, es la entrega en la intimidad misma de la vida de Dios, posibilitada por la unión en Cristo y realizada en un grado tal que la naturaleza humana es capaz de dar a Dios sus propios dones en un cambio recíproco.

Gregorio ha expresado la idea de reciprocidad a partir de ciertos símbolos que nos abren a una mejor comprensión de la posibilidad del alma en alcanzar lo divino. Los símbolos que expresan tal situación son el árbol, la fuente, el alimento y el perfume.

\section{El árbol}

En el contexto simbólico es una de las figuras que expresa la interioridad, es el árbol fecundo cuyas ramas se encuentran cubiertas de frutos. Sin embargo, los roles entre Dios y el hombre se invierten; la Esposa que había recolectado los frutos del manzano llega a ser ella un fruto maduro, que ahora Dios desea recolectar: "mira al Esposo el alma purificada, hecha ya manzana en el árbol de la selva" (7). El alma ha tenido acceso a la divinidad, se ha hecho manzana a causa de la perfecta y completa humanidad de Cristo.

\section{La fuente}

Al comienzo del Cantar la fuente es símbolo de Dios que hace brotar en el alma la vida; esto porque la Esposa desea, mediante un beso, aproximar su boca a la boca divina: el alma, la joven niña, quiere aproximarse a la fuente de la vida espiritual. Esta fuente es la boca del Esposo de donde brotan palabras de vida eterna para saciar la boca sedienta; como hacía el profeta cuando atraía a su boca el Espíritu. Aquel que bebe el agua de la fuente debe aproximar su boca a la boca cuya fuente es el Señor que dice: "si alguno tiene sed que venga a mí y beba", Jn 7,37; también el alma sedienta quiere aproximar su propia boca a la boca que hace brotar la vida y dice: "que me bese con los besos de su boca" (8) $\mathrm{Ct}$ 1,2. El alma atrae hasta sus labios aquella boca que es manantial; el Esposo hace brotar de la fuente la vida que

(6) Cf. Canévet Mariette, op. cit., 342-347.

(7) CCEE IV, 72.

(8) CCEF I, 51. 
es para todos (9). Mediante la expresión del beso se describe la posibilidad de encuentro y unión entre los Esposos, esta vez propiciado por el gozo y el deseo de la Esposa quien declara no estar satisfecha. Según Gregorio los dos se tocan en el beso, el cual se expresa por el sentido del tacto, y es el alma quien poseyendo tal sentido toca al Verbo (10).

En la Segunda Homilía el alma demanda al Bien amado que le permita conocer dónde lleva su rebaño: "dime dónde moras para que, habiendo hallado tus pastos de salvación me sacie de un alimento celeste, del que todo hombre debe comer para entrar en la vida eterna. Correr hacia ti que eres la fuente y aspirar del brebaje divino que haces surgir para aquellos que tienen sed. Tú haces correr esta agua de tu costado... y cualquiera que la guste se convierte en fuente de agua que salta hasta la vida eterna" (11). Esta es la reciprocidad entre Dios y el alma donde el cambio se efectúa simultáneamente, en efecto, el alma llega a ser fuente y ella es ahora, quien atrae la gracia divina.

\section{El alimento}

Esta actitud de reciprocidad resuena al interior del alma, pues ella no recibe un alimento que no penetre en su propia vida. En la medida que recibe un alimento transformante se transforma enteramente, es afectada; de este modo podemos también decir que la belleza que recibe y acoge en su interior se muestra y transparenta hacia el exterior. Todas estas virtudes entregadas al interior del alma se muestran y embellecen a quien las contiene (12). El alimento es símbolo de la comunicación interior de la gracia: "el que come este pan vivirá", Jn 6,58 se lee en el Evangelio.

Sin embargo, es preciso subrayar que el alma, por ella misma, en razón de sus propias fuerzas, no llegará jamás a ser fruto ni alimento para los demás hombres. Debido a esta índole, Gregorio hace referencia al concepto de participación del alma. Es ella quien posibilitada por el Esposo puede ser afectada de todos los bienes y hacer visible a Aquel a quien ha acogido en su interioridad.

\section{El Perfume}

En el Cantar 1,2 "Ungüento derramado es tu nombre" (13) significa la inefabilidad de lo divino y en cierto sentido el alma puede percibirlo aunque sea a modo de vestigio. Esta idea Gregorio la desarrolla en la línea de 2 Cor 2,15: "somos para Dios suave olor de Cristo". Por esta razón este perfume hace que el alma se convierta "en buen olor de Cristo", pues el mismo Jesús nace en quienes lo recibieron y crece en ellos en sabiduría y gracia. Por esto podemos decir que en las Homilías In Canticum el nardo perfumante pasa del Esposo a la Esposa (14).

(9) Cf. Canévet Mariette, op. cit., 344.

(10) CCEE I, 25

(11) In Cant. II, GNO 6, p. 62,1-7; CCEF II, 69-70.

(12) Cf. Canévet Mariette, op. cit., 343-344.

(13) CCEE I, 27

(14) CCEE III,58. 
En síntesis, las imágenes cristológicas del árbol, la fuente, el alimento y el perfume posibilitan al alma, mediante la unión en Cristo, hacerse semejante a Cristo, transformándose en fruto maduro, convirtiéndose en fuente, llegando a ser alimento y recibiendo el buen olor. Esta transformación se realiza de un modo tal, que posibilita a la naturaleza humana alcanzar a Dios y responder con sus propios dones en un sentido de reciprocidad. Gregorio sabe que la razón de esta configuración, como lo expresa en su obra, debe su origen a Dios, quien nos llama a participar de sí mismo en el más perfecto y feliz camino de salvación que es el amor (15). Así, en las Homilías la expresión simbólica de las bodas profundizará las relaciones de reciprocidad.

\section{SIMBOLISMO CONYUGAL: RELACIONES DE RECIPROCIDAD Y PARADOJA}

\section{Simbolismo conyugal}

Se reconoce que el simbolismo conyugal es una forma original y profundamente lírica para expresar el amor de Dios con su pueblo. Es por una transposición que tanto la exégesis judía y la cristiana han podido reconocer en el Bien amado, al novio, y en la novia del Cantar de los Cantares las figuras de Dios e Israel.

De esta manera, el binomio Esposo-Esposa es integrada a la serie de coplas que en la literatura bíblica sirven de imágenes de la alianza. Son los intérpretes místicos de la Biblia que insisten sobre todo en el amor como simbolismo conyugal. Este se encuentra cargado de significaciones y no implica solamente una alianza, sino corresponde a una verdad dialéctica de la alianza que religa a dos seres que eran necesariamente diferentes y por la identidad que les ofrece el amor pueden ahora experimentarse el uno por el otro (16).

Según una nueva noción y abandonando el simbolismo de la sujeción y dependencia, el hombre puede entonces situarse ante Dios Señor y Creador, dejando de ser servidor y creatura, pues el uso de contrarios es demasiado exorbitante y eminentemente el uno superior al otro (17).

De este modo, en el simbolismo conyugal la relación de amantes y compañeros, por el amor los hace iguales. Son amantes capaces de identificarse el uno en el otro, invocándose en un diálogo armonioso y recíproco. No de otro modo, la metáfora del amor conyugal permite concebir una alianza equitativa entre Dios y el hombre, presentes en las Homilías In Canticum a partir de esta igualdad, participación, conformación expresada mediante una relación recíproca, propia y constitutiva de los amantes.

La vocación nupcial destacada en la obra del Niseno arranca a partir de las relaciones mutuas entre dos protagonistas: la Esposa toda vuelta hacia Dios, quien

(15) Cf. CCEE I, 16.

(16) Cf. Neher, A., Le symbolisme conjugal; expression... En: Revue de Histoire et de Philosophie Religieuses (1954) 34.

(17) Cf. Neher, A., op. cit., 37-38. 
se sitúa en un camino de búsqueda y encuentro, en un movimiento siempre ascendente. Esta experiencia de los bienes divinos vuelve al alma hacia los bienes superiores; este es el llamado que ella siente; sin embargo, se produce un cambio nuevo: en el impulso de la Esposa hacia Dios responde una incitación que proviene de parte de Él y por ello manifiesta: "Ven amada mía" (18). Por ello los Esposos son amantes el uno del otro y se invocan en términos de igualdad.

Ella dice: “Estoy herida de amor”. ¡Hermosa herida, dulce llaga!” (19). Se alaba al arquero porque lanza la flecha con perfección. Se dirige entonces el alma de ascensión en ascensión hasta llegar a lo más alto. Con ello viene la vida interior y por el orificio ha quedado abierta una puerta para Dios (20).

En síntesis, este movimiento en ascenso, siempre más alto, es característico en la espiritualidad de Gregorio sin embargo, la reciprocidad se opera en el hecho que el ascenso no es solo ascenso, sino también profundidad en las relaciones.

\section{Relaciones de reciprocidad y paradoja}

La reciprocidad se traduce a nivel de la alegría expresada por los novios, donde el uno y el otro intercambian su amor gracia por gracia. En estos términos escuchamos las palabras de la Esposa cuando dice: Mi Bien amado es para mí y yo soy para Él. Esta forma de actuar se sitúa bajo el prisma del simbolismo conyugal, uno de los temas favoritos de la literatura profética del Antiguo Testamento y del cual Gregorio se hace cargo en las Homilías.

Las relaciones de reciprocidad y la paradoja marcan la introducción del alma en la vida divina, es decir, en la vida trinitaria -por ello Gregorio inicia el tema con una cita: "Nadie puede decir Señor Jesús, sino en el Espíritu Santo” 1 Cor 12,3. Es en Cristo donde el alma tiene acceso a la divinidad-. Estos dos aspectos esenciales de la vida espiritual se encuentran fundados en las palabras de la Escritura. Sobre todo en los autores bíblicos más utilizados por Gregorio: San Pablo y el evangelista Juan (21). La Esposa se siente atraída por las promesas de la Sabiduría en Prov 8,17: "Yo amo a aquellos que me aman", pues dice el comentario, "esperando la respuesta de amor se acrecienta el deseo del amante" (22). El alma percibe que ella responde en realidad a un amor que primero viene de Dios, en la terminología de Juan 15,13 "no hay amor más grande que dar la vida por sus amigos" (23). Así es el rol esencial que cumplen las palabras de Juan 6,56: "Quien come mi carne y bebe mi sangre está en Mí y yo en él”.

En síntesis, la reciprocidad se transforma en paradoja en cuanto se quiere ofrecer a Aquel que es el origen de toda ofrenda (24).

(18) Cf. Canévet Mariette, op. cit., 346.

(19) CCEE IV,77.

(20) Cf. CCEE IV, 77.

(21) Cf. Canévet Mariette, op. cit., 346.

(22) In Cant I, GNO 6, P 22, 1-2.

(23) CCEE II, 41.

(24) Cf. Canévet Mariette, op. cit., 347 


\title{
CONCLUSIÓN:
}

La teología que elabora Gregorio, a partir de concepciones filosóficas de la época, la desarrolla en un grado tal que permite teológica y filosóficamente hablando hacer referencia a la posibilidad del alma para alcanzar lo divino. Una vez alcanzado lo divino, por la mediación de Cristo y donde toda la naturaleza humana ha sido invitada a participar, se supera la distancia de la realidad finita-infinita, siendo la gracia expresión dinamizante y progresiva de esta participación.

Entonces, por la gracia del Redentor y por su pasión es posible superar el gran abismo entre estas realidades y paradójicamente el hombre podrá corresponder a Dios, en un cambio recíproco de dones.

\section{RESUMEN}

Gregorio de Nisa ha subrayado la diferencia entre la naturaleza del ser creado y del ser increado, entre el ser finito y el ser infinito, entonces ¿podría plantearse la idea que el hombre inmerso en este movimiento infinito hacia el infinito nunca podrá alcanzar la ansiada posesión del Bien? Gregorio sitúa el carácter indefinido de la búsqueda, pero ello no significa que Dios sea inalcanzable. El alma tiene acceso a la divinidad posibilitada por la única mediación de Cristo, quien es Dios verdaderamente.

Una vez situada la naturaleza humana en su dimensión de horizontalidad con Dios se expresará la alegría del encuentro mediante los símbolos de reciprocidad, donde la naturaleza humana es capaz de ofrecer a Dios sus propios dones, que paradójicamente corresponden a frutos que ha recibido por gracia, haciendo visible a Aquel a quien ha acogido en su interioridad.

\begin{abstract}
Saint Gregory of Nissa has emphasi sed the difference between the nature of the created being and the uncreated one, between the finite being and the infinite one. If that is so, the author wonders whether Man, immersed in this infinite movement towards the infinite, will ever be able to attain his desired possession of the God. Gregory deal with the indefinite character of this search, but without meaning that God is unattainable. The soul has access to the divinity accomplished through Christ's mediation, who is truly God.

Once the human nature is placed in a horizontal dimension with God, the joy if such encounter will be expressed by means of symbols of recipro city. Then, human nature is capable of offering God, its own goods, which paradoxically correspond to the fruits received by grace, making visible the One he has received in his own interiority.
\end{abstract}

